\section{In Vitro Regeneration through Direct Organogenesis from Protocorms of Oncidium tigrinum Llave \& Lex. (Orchidaceae), an Endemic and Threatened Mexican Species}

\author{
Martín Mata-Rosas ${ }^{1}$ and Rosario Julieta Baltazar-García \\ Instituto de Ecología, A.C., Red Manejo Biotecnológico de Recursos, Carretera \\ antigua a Coatepec $N^{\circ}$ 351, El Haya, Xalapa, Veracruz, 91070, México
}

Victor Manuel Chávez-Avila

Jardín Botánico, Instituto de Biología, Universidad Nacional Autónoma de México, 04510, México

Additional index words. micropropagation, orchids, organogenesis, conservation

\begin{abstract}
A protocol for in vitro propagation from protocorms of Oncidium tigrinum Llave \& Lex., a threatened species distributed in Mexico and highly appreciated as an ornamental, was developed. Two different explants, entire protocorms and longitudinal halves of protocorms, were used. In addition, the effect of two different culture media, Murashige and Skoog (MS) and modified Knudson $(\mathrm{KCm})$, supplemented with $\mathbf{N}^{6}$ benzyladenine (BA) $\left(0,0.5,1,2,3\right.$, and $\left.5 \mathrm{mg} \cdot \mathrm{L}^{-1}\right)$ and/or $\alpha$-naphthaleneacetic acid (NAA) at $0,0.1$, and $0.5 \mathrm{mg} \cdot \mathrm{L}^{-1}$ was investigated. Adventitious shoot formation by direct organogenesis was obtained in all treatments; in some cases, the formation of protocormlike bodies was induced. Shoot formation was greater for entire protocorms; the best treatment was MS medium containing at BA 1 to $2 \mathrm{mg} \cdot \mathrm{L}^{-1}$ in combination with at NAA $0.1 \mathrm{mg} \cdot \mathrm{L}^{-1}$. The average height of shoots was three times greater in MS medium than in KCm medium. Subculturing individual shoots in MS medium without plant growth regulators, but with $1 \mathrm{~g} \cdot \mathrm{L}^{-1}$ activated charcoal, allowed further development and rooting. An ex vitro survival rate of almost $100 \%$ was achieved. This study represents a comprehensive application for propagation, conservation, and sustainable use of this valuable natural resource.
\end{abstract}

A total of 1254 species of orchids is found in Mexico, including 37 species of the genus Oncidium (Soto-Arenas et al., 2007), which are highly variable with respect to both plant and flower size (Soule, 1981). Oncidium is endemic to the American continents; it includes species with great ornamental value from which several sought-after varieties and hybrids have been produced (Batchelor, 1980).

One Oncidium species, Oncidium tigrinum, is an epiphytic species endemic to Mexico (Fig. 1A). It occurs from Jalisco to Michoacán in the Trans-Mexican Volcanic Belt and Sierra Madre del Sur mountain range in southern Mexico. The native habitats of this species include temperate oak forests and pine-oak forests at an altitude of $2500 \mathrm{~m}$ (Jiménez et al., 1998). Naturally occurring populations have been reduced by the collection of wild

\footnotetext{
Received for publication 10 Mar. 2011. Accepted for publication 11 June 2011.

We thank David Moreno for the photo of $O$. tigrinum and Pamela Moon for the suggestions and corrections of the English text. Rosario Baltazar thanks Instituto de Ecología, A.C. for the grant offered to conduct his professional studies.

${ }^{1}$ To whom reprint requests should be addressed; e-mail martin.mata@inecol.edu.mx.
}

specimens to satisfy commercial demand and by habitat alteration. Consequently, this species is protected by the Mexican government and listed as a threatened species (Jiménez et al., 1998; SEMARNAT, 2002). Tissue culture techniques have been used to propagate and conserve endangered orchid species (Sarasan et al., 2006) and reports of such research with native Mexican orchid species are becoming increasingly common (Ávila-Díaz et al., 2009; Damon et al., 2004; Lee-Espinosa et al., 2007; Mata-Rosas and Salazar-Rojas, 2009; Mata-Rosas et al., 2010; SantosHernández et al., 2005). Nevertheless, it is critical to establish new protocols for efficient in vitro regeneration; direct organogenesis is the preferred technique so that genetic stability is being obtained in the regenerated plantlets (George, 1993).

Despite the importance of Oncidium in horticulture, there are few studies concerning in vitro propagation, but most studies focus on artificial hybrids, not species. Commonly used explants for micropropagation are: inflorescence buds (Chen and Chang, 2000a), microinflorescences (Kerbauy, 1984a), leaves (Chen et al., 1999), inflorescence buds (Arditti, 1977; Nuraini and Shaib, 1992), apical buds (Kerbauy, 1984b), roots (Kerbauy, 1984b), and other meristematic areas (Arditti, 1977).
However, regeneration from protocorms has not been reported. With regard to $O$. tigrinum, no reports on micropropagation have been found, except a report on its use as a parent in the development of hybrids (Batchelor, 1980).

We evaluated the efficacy of 1) $\mathrm{KCm}$ and MS; and 2) varying concentrations of BA and/or NAA on the induction of shoot and protocorm-like bodies (PLBs) of $O$. tigrinum as well as the subsequent survival of plantlets ex vitro.

\section{Materials and Methods}

Seed sterilization. Seeds of $O$. tigrinum, produced through hand-pollination, were obtained from the Francisco Javier Clavijero Botanical Garden, Xalapa, Veracruz. After ripe capsules opened, the seeds were collected and stored in paper envelopes for $15 \mathrm{~d}$ at $5{ }^{\circ} \mathrm{C}$ before use. Seeds were surface-sterilized by placing them in a $5-\mathrm{mL}$ sterile syringe; $5 \mathrm{~mL}$ of $3 \%$ hydrogen peroxide (Kurak $\left.{ }^{\circledR}\right)$ was added and the syringe was shaken vigorously for $10 \mathrm{~min}$. Three milliliters of hydrogen peroxide was then decanted; one to two drops of hydrogen peroxide (containing seeds) were introduced into a $125-\mathrm{mL}$ baby food jar containing $25 \mathrm{~mL}$ of medium. Two media were used: 1) inorganic salts and vitamins of MS medium (Murashige and Skoog, 1962) augmented with $2 \mathrm{mg} \cdot \mathrm{L}^{-1}$ glycine, $100 \mathrm{mg} \cdot \mathrm{L}^{-1}$ myo-inositol, and $30 \mathrm{~g} \cdot \mathrm{L}^{-1}$ sucrose (MS medium); and 2) the same basal medium but with $1 \mathrm{~g} \cdot \mathrm{L}^{-1}$ activated charcoal added.

The $\mathrm{pH}$ of each culture medium was adjusted to a $\mathrm{pH}$ of $5.7 \pm 0.1$ with $0.1 \mathrm{~N} \mathrm{NaOH}$ and $0.1 \mathrm{~N} \mathrm{HCl}$ before adding $8 \mathrm{~g} \cdot \mathrm{L}^{-1}$ agar (plant TC/ micropropagation grade; Phytotechnology Laboratories $^{\mathrm{TM}}$ ), then autoclaving at $1.2 \mathrm{~kg} \cdot \mathrm{cm}^{-2}$ and $120^{\circ} \mathrm{C}$ for $17 \mathrm{~min}$. All cultures were incubated in a growth chamber at $25 \pm 1{ }^{\circ} \mathrm{C}$ under a 16-h photoperiod provided by cool white fluorescent lamps $\left(50 \mathrm{mmol} \cdot \mathrm{m}^{-2} \cdot \mathrm{s}^{-1}\right)$.

Induction stage. Germinated protocorms with a diameter of 2 to $3 \mathrm{~mm}$ were selected as explants. Two kinds of explants were used: entire protocorms and longitudinal halves of protocorms. The explants were transferred to two different treatment media: 1) MS medium; and 2) modified KC medium (Knudson, 1946) augmented with the micronutrients used in MS medium $(\mathrm{KCm})$. Both media were supplemented with a combination of BA at concentrations of $0,0.5,1,2,3$, or $5 \mathrm{mg} \cdot \mathrm{L}^{-1}$ and NAA at concentrations of $0,0.1$, or $0.5 \mathrm{mg} \cdot \mathrm{L}^{-1}$. There were 20 replicate jars with three explants per jar (i.e., 60 explants per treatment). The longitudinal halves of protocorms were cultured with the wound surface in contact with culture media. The induction period was $90 \mathrm{~d}$.

Development and separation. When the induction stage was complete, explants were subcultured to their respective basal media (MS and $\mathrm{KCm}$ ) without plant growth regulators and augmented with $1 \mathrm{~g} \cdot \mathrm{L}^{-1}$ activated charcoal so that the shoots that had been formed in the induction phase could develop. Also, individual shoots were detached from shoot clumps using a scalpel and forceps. This was to allow further growth of already formed buds and to 

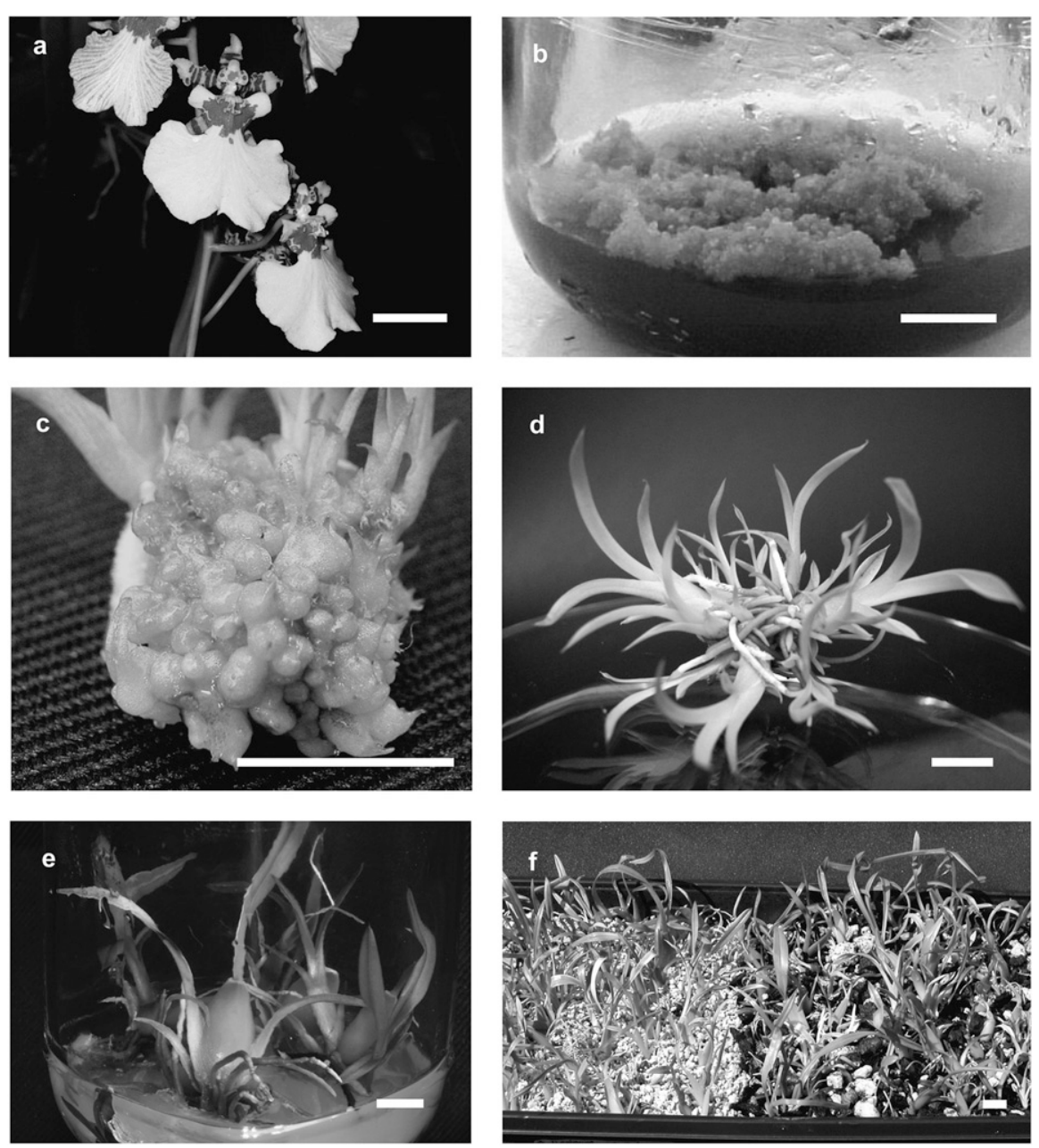

Fig. 1. (A) Flowers of Oncidium tigrinum; (B) Seed germination on Murashige and Skoog (MS) medium with $1 \mathrm{~g} \cdot \mathrm{L}^{-1}$ activated charcoal; (C) PLBs obtained from a few protocorms of $O$. tigrinum cultured in MS medium supplemented with NAA at $0.1 \mathrm{mg} \cdot \mathrm{L}^{-1}$; (D) direct organogenesis from protocorms of $O$. tigrinum cultured in MS with BA $1 \mathrm{mg} \cdot \mathrm{L}^{-1}$ and NAA $\left.0.1 \mathrm{mg} \cdot \mathrm{L}^{-1} ; \mathbf{E}\right)$ in vitro rooted shoots ready for ex vitro culture; $(\mathbf{F})$ plantlets of $O$. tigrinum after successful establishment in soil for 2 months. Bar $=$ $1 \mathrm{~cm}$. PLBs $=$ protocorm-like bodies; NAA $=\alpha$-naphthaleneacetic acid; $\mathrm{BA}=\mathrm{N}^{6}$-benzyladenine

promote the development of the smaller buds. The height of shoots and plantlets was measured from the base of the pseudobulb to the tip of the longest leaf. The number of shoots per explant and the number of PLBs per explant were recorded.

Ex vitro culture. After 9 months of in vitro culture, the effects of explant type, culture medium, plant growth regulator (PGR), and type of substrate on ex vitro plantlet survival were evaluated.

The plantlets were removed from the jars and washed thoroughly under tap water to remove all adhering culture medium. They were then transferred to propagation trays (Hummert International $\mathrm{l}^{\mathrm{TM}}$ ) and placed in a greenhouse with an average temperature of $30{ }^{\circ} \mathrm{C}$. For the first $30 \mathrm{~d}$, a high relative humidity $(80 \%$ to $90 \%$ ) was maintained by keeping the trays covered with plastic, translucent lids (Hummert International ${ }^{\mathrm{TM}}$ ). The relative humidity was then reduced to between $50 \%$ and $60 \%$. To avoid fungal diseases, $1.5 \mathrm{~g} \cdot \mathrm{L}^{-1}$ of methyl $\mathrm{N}-[1$ (butylcarbamoyl)benzimidazol-2-yl]carbamate and $1.5 \mathrm{~g} \cdot \mathrm{L}^{-1}$ of 2,4,5,6-tetrachloroisophthalonitrile solution were applied. Two different soils were tested: 1) pumice; and 2) pine bark:oak charcoal:pumice (1:1:1). Plantlet survival and height were recorded once a month for 4 months.

Statistical analysis. The number of shoots per explant and the height of shoots were analyzed using analysis of variance and means were compared by Duncan's multiple range test $(P \leq 0.05)$. In addition, to assess the robustness of our results with respect to the normality assumption, the Kruskal-Wallis test was used.

\section{Results}

Seed germination in each of the two culture media was close to $100 \%$ (Fig. 1B). After $30 \mathrm{~d}$, protocorms were 2 to $3 \mathrm{~mm}$ in diameter to be used as a source of explants.

Effect of explants. When evaluating the performance of each kind of explant (entire protocorms and longitudinal halves of protocorms), the former showed a higher response rate; that is, $90.3 \%$ and $89.7 \%$ of entire protocorms responded when they were cultured on MS and KCm media, respectively. Only $19.8 \%$ and $7.6 \%$, respectively, of longitudinal halves of protocorms responded when they were cultured on MS and $\mathrm{KCm}$ media. Most of these explants turned brown and died within a few days. As a result of the poor results obtained with these explants, only the cultures derived from entire protocorms were tracked for the rest of the experiment.

Shoot formation. The main morphogenetic response obtained in each of the media was the formation of adventitious shoots by direct organogenesis. In some cases, the formation of PLBs was induced (Fig. 1C).

Shoot formation was observed after $30 \mathrm{~d}$ of culture regardless of treatment. The protocorms increased in size and acquired a wrinkled, green surface with nodular protuberances. In some cases, primordial leaves were formed at the apex of the protocorm. Over the next $30 \mathrm{~d}$, small shoots and small green primordial leaves appeared around the explants. PLBs formed in the basal section of a few explants. These were easily detached.

Growth of adventitious shoots continued during the last $30 \mathrm{~d}$ of the induction stage. The shoots produced leaves and, in some cases, roots and pseudobulbs. During the induction stage, shoots remained attached to the explant. The percentage of explants with formation of PLBs was very low (5\%) and occurred without respect to treatment. Only very few of the PLBs developed into plantlets. The remaining PLBs induced the formation of secondary PLBs in a process that continued throughout the course of the experiment.

Effect of plant growth regulators. Shoot formation differed significantly among treatments $(P \leq 0.05)$. The average number of shoots per explant was greater for the MS treatments than for those from $\mathrm{KCm}$ (Table 1). The most shoots per explant (20.93 and 20.85) occurred in the treatments containing $0.1 \mathrm{mg} \cdot \mathrm{L}^{-1}$ of NAA in combination with 2 and $1 \mathrm{mg} \cdot \mathrm{L}^{-1} \mathrm{BA}$, respectively (Fig. 1D). In these treatments, $100 \%$ of explants responded. In contrast, for the $\mathrm{KCm}$ treatment supplemented with $0.5 \mathrm{mg} \cdot \mathrm{L}^{-1}$ of each PGR, the average number of shoots per explant was 19.7 and only $80 \%$ of explants responded. Other MS treatments with high shoot formation were those in which BA was the only PGR added; in these treatments, the average number of shoots per explant ranged from 11.35 to 17.9 (Table 1). In addition to the low levels of shoot formation in most $\mathrm{KCm}$ treatments, the shoots that developed on these media were yellowish in color. In contrast, the shoots obtained from MS treatments were a deeper green color that was similar to that of wild plants.

Height. Average shoot height was three times greater for the MS treatments than for the $\mathrm{KCm}$ treatments (Table 1). The MS treatment with $0.5 \mathrm{mg} \cdot \mathrm{L}^{-1} \mathrm{NAA}$ and $3 \mathrm{mg} \cdot \mathrm{L}^{-1} \mathrm{BA}$ produced the greatest average shoot length (4.62 $\mathrm{cm})$. However, the MS treatment that was augmented with $0.1 \mathrm{mg} \cdot \mathrm{L}^{-1} \mathrm{NAA}$ and $1 \mathrm{mg} \cdot \mathrm{L}^{-1}$ $\mathrm{BA}$ produced shoots with an average length of $4.45 \mathrm{~cm}$, which was the second greatest of any treatment and this treatment also yielded one of the greatest average numbers of shoots per explant. Thus, addition of PGRs not only 
Table 1. Effect of different concentrations of NAA and BA on shoot formation and height of cultured protocorms of Oncidium tigrinum on two different basal media (MS and $\mathrm{KC}$ ) formulations.

\begin{tabular}{|c|c|c|c|c|c|}
\hline Medium & $\begin{array}{c}\mathrm{NAA} \\
\left(\mathrm{mg} \cdot \mathrm{L}^{-1}\right)\end{array}$ & $\begin{array}{c}\mathrm{BA} \\
\left(\mathrm{mg} \cdot \mathrm{L}^{-1}\right)\end{array}$ & $\begin{array}{c}\text { Percent of } \\
\text { responding explants }\end{array}$ & $\begin{array}{c}\text { Avg number of } \\
\text { shoots per explant }\end{array}$ & $\begin{array}{c}\text { Avg ht of } \\
\text { shoots }(\mathrm{cm})\end{array}$ \\
\hline \multirow[t]{18}{*}{$\overline{\mathrm{MS}}$} & 0 & 0 & 95 & $15.33 \pm 3.40 \mathrm{abcde}^{\mathrm{z}}$ & $2.92 \pm 0.27 \mathrm{fg}$ \\
\hline & 0 & 0.5 & 100 & $16.02 \pm 4.58$ abcde & $3.24 \pm 0.24 \mathrm{efg}$ \\
\hline & 0 & 1 & 100 & $11.35 \pm 1.88$ abcdef & $2.87 \pm 0.22 \mathrm{~g}$ \\
\hline & 0 & 2 & 100 & $16.75 \pm 3.49 \mathrm{abcd}$ & $3.04 \pm 0.17 \mathrm{fg}$ \\
\hline & 0 & 3 & 95 & $17.88 \pm 4.30 \mathrm{a} \mathrm{bcd}$ & $3.3 \pm 0.25 \mathrm{~d}$ efg \\
\hline & 0 & 5 & 100 & $17.73 \pm 4.16 \mathrm{abcd}$ & $3.27 \pm 0.19 \mathrm{defg}$ \\
\hline & 0.1 & 0 & 85.0 & $10.75 \pm 2.06$ abcdef & $3.39 \pm 0.37 \mathrm{defg}$ \\
\hline & 0.1 & 0.5 & 100.0 & $10.28 \pm 2.45$ bcdef & $4.08 \pm 0.34$ abcde \\
\hline & 0.1 & 1 & 100.0 & $20.85 \pm 5.79 \mathrm{ab}$ & $4.45 \pm 0.45 \mathrm{ab}$ \\
\hline & 0.1 & 2 & 100.0 & $20.93 \pm 6.42 \mathrm{a}$ & $3.82 \pm 0.29$ abcdef \\
\hline & 0.1 & 3 & 100.0 & $13.05 \pm 2.20$ abcde & $3.67 \pm 0.23$ bcdefg \\
\hline & 0.1 & 5 & 100.0 & $13.73 \pm 1.93$ abcde & $3.47 \pm 0.32$ cdefg \\
\hline & 0.5 & 0 & 15.0 & $1.68 \pm 0.95 \mathrm{f}$ & $0.86 \pm 0.48 \mathrm{hi}$ \\
\hline & 0.5 & 0.5 & 75.0 & $8.97 \pm 2.97 \mathrm{def}$ & $3.73 \pm 0.63$ bcdefg \\
\hline & 0.5 & 1 & 85.0 & $11.02 \pm 2.81$ abcdef & $4.18 \pm 0.46 \mathrm{abcd}$ \\
\hline & 0.5 & 2 & 85.0 & $12.6 \pm 3.1 \mathrm{abcde}$ & $3.58 \pm 0.48$ bcdefg \\
\hline & 0.5 & 3 & 95.0 & $12 \pm 2.23$ abcde & $4.62 \pm 0.35 \mathrm{a}$ \\
\hline & 0.5 & 5 & 95.0 & $15.38 \pm 2.68$ abcde & $4.33 \pm 0.39 \mathrm{abc}$ \\
\hline \multirow[t]{18}{*}{$\mathrm{KC}$} & 0 & 0 & 100.0 & $13.82 \pm 4.80$ abcde & $1.32 \pm 0.09 \mathrm{hi}$ \\
\hline & 0 & 0.5 & 100.0 & $6.2 \pm 1.23 \mathrm{ef}$ & $1.5 \pm 0.12 \mathrm{hi}$ \\
\hline & 0 & 1 & 100.0 & $13.28 \pm 2.32$ abcde & $1.3 \pm 0.12 \mathrm{hi}$ \\
\hline & 0 & 2 & 95.0 & $11.22 \pm 1.74$ abcdef & $1.27 \pm 0.11 \mathrm{hi}$ \\
\hline & 0 & 3 & 90.0 & $11.78 \pm 2.21$ abcde & $1.38 \pm 0.15 \mathrm{hi}$ \\
\hline & 0 & 5 & 100.0 & $14.75 \pm 2.22$ abcde & $1.35 \pm 0.11 \mathrm{hi}$ \\
\hline & 0.1 & 0 & 65.0 & $8.67 \pm 2.48 \mathrm{def}$ & $0.7 \pm 0.15 \mathrm{i}$ \\
\hline & 0.1 & 0.5 & 95.0 & $13.13 \pm 2.54$ abcde & $1.37 \pm 0.13 \mathrm{hi}$ \\
\hline & 0.1 & 1 & 95.0 & $13.62 \pm 2.43$ abcde & $1.56 \pm 0.16 \mathrm{hi}$ \\
\hline & 0.1 & 2 & 100.0 & $9.87 \pm 1.22 \mathrm{cdef}$ & $1.67 \pm 0.55 \mathrm{~h}$ \\
\hline & 0.1 & 3 & 85.0 & $9.28 \pm 1.79 \mathrm{cdef}$ & $1.51 \pm 0.19 \mathrm{hi}$ \\
\hline & 0.1 & 5 & 90.0 & $10.38 \pm 1.79$ bcdef & $1.46 \pm 0.17 \mathrm{hi}$ \\
\hline & 0.5 & 0 & 70.0 & $10.1 \pm 3.30 \mathrm{cdef}$ & $0.79 \pm 0.21 \mathrm{hi}$ \\
\hline & 0.5 & 0.5 & 80.0 & $19.7 \pm 4.83 \mathrm{abc}$ & $1.45 \pm 0.31 \mathrm{hi}$ \\
\hline & 0.5 & 1 & 75.0 & $12.77 \pm 3.11$ abcde & $1.28 \pm 0.21 \mathrm{hi}$ \\
\hline & 0.5 & 2 & 90.0 & $12.73 \pm 2.95$ abcde & $1.68 \pm 0.22 \mathrm{~h}$ \\
\hline & 0.5 & 3 & 95.0 & $12.45 \pm 30$ abcde & $1.62 \pm 0.22 \mathrm{hi}$ \\
\hline & 0.5 & 5 & 90.0 & $14.12 \pm 2.65$ abcde & $1.55 \pm 0.19 \mathrm{hi}$ \\
\hline
\end{tabular}

Mean \pm SE.

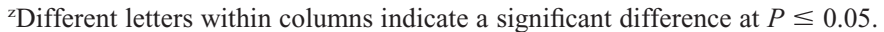

$\mathrm{NAA}=\alpha$-naphthaleneacetic acid $; \mathrm{BA}=\mathrm{N}^{6}$-benzyladenine; $\mathrm{MS}=$ Murashige and Skoog; $\mathrm{KC}=\mathrm{Knudson} \mathrm{C}$.

benefited the formation of shoots through direct organogenesis, but also positively influenced shoot growth of shoots; shoot height was lessened in zero PGR treatments.

Rooting. Growth and development of roots and pseudobulbs were improved when individual shoots were separated from the shoot clumps and transferred to basal MS medium with activated charcoal $\left(1 \mathrm{~g} \cdot \mathrm{L}^{-1}\right)$. The fraction of shoots that rooted was similar for MS $(74.9 \%)$ and $\mathrm{KCm}$ treatments (Fig. 1E). However, the fraction of shoots with pseudobulbs differed between them; rooting was $58.5 \%$ in MS treatments and $37.4 \%$ in $\mathrm{KCm}$ treatments.

Ex vitro development. The ex vitro survival of the plantlets was unaffected by the type of culture media or by the type of soil. All plantlets survived, except in three treatments in which the fraction of plants that survived was slightly lower (data not shown). With continued watering and fertilization, the plantlets grew and developed new leaves. Additionally, those plantlets that did not possess pseudobulbs at the time of planting produced them ex vitro (Fig. 1F).

\section{Discussion}

With in vitro propagation studies, especially when conservation of endangered species is involved, seeds are the most commonly used and recommended explants because they have great regenerative capacity and are the main source of genetic diversity (Ramsay and Dixon, 2003).

Several culture media formulations can be used for in vitro germination of orchid seeds (Yam and Weatherhead, 1988). In some cases, simple media such as $\mathrm{KCm}$ and some others like MS at one-fourth to one-half strength have promoted rapid and efficient germination. Germination can be improved by augmenting the culture media with activated charcoal or with undefined organic compounds (Ichihashi, 1991; Mata-Rosas and Salazar-Rojas, 2009; Pedroza-Manrique and Mican-Gutiérrez, 2006; Thompson et al., 2006). In contrast with such previous reports, observed germination in this study was enhanced when using MS medium, which has a higher mineral concentration than $\mathrm{KCm}$. However, similar results have been reported for other orchid species (Ávila-Díaz, et al., 2009; Lo et al., 2004; Sampaio et al., 2010).

Most of the longitudinally halved protocorms turned brown within the first weeks of the induction stage, perhaps because of damage to the tissue at the time of dissection. Rodríguez (2000) similarly reported micropropagation failure when using longitudinally halved protocorms of Paphiopedilum exstaminodium and $P$. caudatum. He suggested the use of different explants for their in vitro propagation.

One reason for sectioning a structure such as a protocorm before use as an explant is that such a procedure can modify endogenous PGR contents, thus promoting a favorable morphogenetic response. In this study, however, protocorm bisection apparently caused severe damage and stress, leading to reduced response rates. Even in those cases in which the explants survived, limited budding or PLB formation was observed. Teixeira da Silva et al. (2006) obtained a similar greater response when using PLB, as opposed to bisected PLBs, as explants. Wounding is often an important factor for organogenesis in orchids, especially with Cattleya, Phalaenopsis, and Cymbidium; browning or blackening caused by postwounding polyphenol oxidase after production is problematic.

In our study, the concentration and kind of PGR as well as the basal medium composition significantly influenced the number of shoots produced per explants; protocorm-cultured MS medium formed more and larger shoots than on $\mathrm{KCm}$. In several studies in which different culture media were used, MS medium was found to be superior (Bhadra and Hossain, 2003; Geetha and Shetty, 2000; Hernández et al., 2001; Kishi and Takagi, 1997). Particularly for reports of in vitro propagation of Oncidium species and hybrids, variants of MS medium were used (Chen and Chang, 2000a, 2000b, 2002, 2003; Li et al., 2005; Sampaio et al., 2010).

Arditti and Ernst (1984) mentioned that in vitro orchid growth can be correlated with the proportion of nitrogen in total ion concentration as well as the form of nitrogen used in the culture medium. Ion concentration was very different for the two culture media used in this study; MS medium has a total ionic concentration of $95.75 \mathrm{~mm}$, which was approximately three times higher than $\mathrm{KCm}(33.39 \mathrm{~mm})$ (George, 1993). Concentrations of ammonium and nitrate nitrogen in $\mathrm{KCm}$ medium are $7.56 \mathrm{~mm}$ and $8.46 \mathrm{~mm}$, respectively, whereas for MS medium, concentrations are 20.61 and $39.40 \mathrm{~mm}$, respectively. This nutritional difference between the media undoubtedly influenced the shoot formation and the growth of the $O$. tigrinum plantlets.

BA was necessary for the highest shoot induction from protocorms of $O$. tigrinum, and it was possible to induce a better response by adding low concentrations of NAA. Similar results have been reported for other orchid species. Shoot formation was most frequent in media to which both PGRs had been added. Similarly, direct shoot formation from leaf explants of Encyclia mariae was most frequent ( 25 shoots per explant) on MS medium containing $5 \mathrm{mg} \cdot \mathrm{L}^{-1} \mathrm{BA}$ and $2 \mathrm{mg} \cdot \mathrm{L}^{-1} \mathrm{NAA}$ (Santos-Díaz and Carranza-Álvarez, 2009). Chen and Chang (2000a) achieved the formation of 2.7 shoots per flower stalk-derived callus of Oncidium Sweet Sugar cultured in half-strength MS augmented with $1 \mathrm{mg} \cdot \mathrm{L}^{-1}$ thidiazuron. 
The protocol and results of this study provide a precise description of the conditions necessary for the propagation of $O$. tigrinum from protocorms. However, the response could be improved by slight modifications of PGR concentrations used here. Alternatively, a different cytokinin could be tested. For example, thidiazuron has been commonly used in propagation of several orchids with great results (Ket et al., 2004; Mata-Rosas and Salazar-Rojas, 2009; Mata-Rosas et al., 2010).

The plantlets obtained in the present study could be used either as material for further research or to satisfy horticultural demand, thus reducing pressure on wild populations. Therefore, this research represents a direct contribution to the conservation and sustainable use of this valuable natural resource.

\section{Literature Cited}

Arditti, J. 1977. Clonal propagation of orchids by means of tissue culture-A manual. In: Arditti, J. (ed.). Orchid biology. Reviews and perspectives I. Comstock Publishing. Cornell University Press, Ithaca, NY, and London, UK.

Arditti, J. and R. Ernst. 1984. Physiology of germinating orchid seeds. In: Arditti, J. (ed.). Orchid biology. Reviews and perspectives, III. Cornell University Press, New York, NY.

Ávila-Díaz, I., K. Oyama, C. Gómez-Alonso, and R. Salgado-Garciglia. 2009. In vitro propagation of the endangered orchid Laelia speciosa. Plant Cell Tissue Organ Cult. 99:335-343.

Batchelor, S.R. 1980. Oncidium maculatum, Oncidium tigrinum and their hybrids. Amer. Orch. Soc. Bull. 49:501-508.

Bhadra, S.K. and M.M. Hossain. 2003. In vitro germination and micropropagation of Geodorum densiflorum (Lam.) Schltr., an endangered orchid species. Plant Tiss. Cult. 13:165-171.

Chen, J.T., C. Chang, and W.C. Chang. 1999. Direct somatic embryogenesis on leaf explants of Oncidium Gower Ramsey and subsequent plant regeneration. Plant Cell Rep. 19:143-149.

Chen, J.T. and W.C. Chang. 2000a. Plant regeneration via embryo and shoot bud formation from flower-stalk explants of Oncidium Sweet Sugar. Plant Cell Tissue Organ Cult. 62:95-100.

Chen, J.T. and W.C. Chang. 2000b. Efficient plant regeneration through somatic embryogenesis from callus cultures of Oncidium (Orchidaceae). Plant Sci. 160:87-93.

Chen, J.T. and W.C. Chang. 2002. Effects of tissue culture conditions and explant characteristics on direct somatic embryogenesis in Oncidium 'Gower Ramsey'. Plant Cell Tissue Organ Cult. 69:41-44.

Chen, J.T. and W.C. Chang. 2003. Effects of $\mathrm{GA}_{3}$, ancymidol, cycocel and paclobutrazol on direct somatic embryogenesis of Oncidium in vitro. Plant Cell Tissue Organ Cult. 72:105-108.

Damon, A., E. Aguilar-Guerrero, L. Rivera, and V. Nikolaeva. 2004. Germinación in vitro de semillas inmaduras de tres especies de orquídeas de la región del Soconusco, Chiapas, México.
Revista Chapingo Serie Horticultura 10:195204.

Geetha, S. and S.A. Shetty. 2000. In vitro propagation of Vanilla planifolia, a tropical orchid. Curr. Sci. 79:886-889.

George, E.F. 1993. Plant propagation by tissue culture. Exegetics Ltd., England, Edington, Wilts, UK, p. 441.

Hernández, H.J., S.O. Hernández, and R.M. Mata. 2001. Regeneración de plántulas a partir del cultivo in vitro de mitades de protocormos de Laelia anceps Lindl. y Catasetum intergerrimum Hook. Amaranto 14:3-12.

Ichihashi, S. 1991. Development of media for aseptic seed germination of Dendrobium. Bull. Aichi Univ. Edu. 40:95-100.

Jiménez, M.R., S.L. Sánchez, J. García-Cruz. 1998. Familia Orchidaceae. Tribu Maxillarieae. Flora del Bajío y de regiones adyacentes. Fasc. 67.

Kerbauy, G.B. 1984a. In vitro flowering of Oncidium varicosum mericlones (Orchidaceae). Plant Sci. Lett. 35:73-75.

Kerbauy, G.B. 1984b. Plant regeneration of Oncidium varicosum (Orchidaceae) by means of root tip culture. Plant Cell Rep. 3:27-29.

Ket, N.V., E.J. Hahn, S.Y. Park, D. Chakrabarty, and K.Y. Paek. 2004. Micropropagation of an endangered orchid Anoectochiuls formosanus. Biol. Plant. 48:339-344.

Kishi, F. and K. Takagi. 1997. Analysis of medium components used for orchid tissue culture. Lindleyana 12:158-161.

Knudson, L. 1946. A new nutrient solution for the germination of orchid seeds. Amer. Orch. Soc. Bull. 15:214-217.

Lee-Espinosa, H.E., A. Laguna-Cerda, J. MurguíaGonzález, P. Elorza-Martínez, L. IglesiasAndreu, B. García-Rosas, F.A. Barredo-Pool, and N. Santana-Buzzy. 2007. Regeneración in vitro de Laelia anceps ssp. dawsonii. Revista Científica UDO Agrícola 7:58-67.

Li, S., C. Kuoh, Y. Chen, H. Chen, and W. Chen. 2005. Osmotic sucrose enhancement of singlecell embryogenesis and transformation efficiency in Oncidium. Plant Cell Tissue Organ Cult. 81:183-192.

Lo, S.F., S.M. Nalawade, C. Kuo, L. Chao-Lin, C.L. Chen, and H.S. Tsay. 2004. Asymbiotic germination of immature seeds, plantlet development and ex vitro establishment of plants of Dendrobium tosaense Makino-A medicinally important orchid. In Vitro Cell. Dev. Biol. Plant 40:528-535.

Mata-Rosas, M., R.J. Baltazar-García, P. Moon, P. Hietz, and V.E. Luna-Monterrojo. 2010. In vitro regeneration of Lycaste aromatica (Graham ex Hook) Lindl. (Orchidaceae) from pseudobulb sections. Plant Biotechnol. Rep. 4:157-163.

Mata-Rosas, M. and V.M. Salazar-Rojas. 2009. Propagation and establishment of three endangered Mexican orchids from protocorms. HortScience 44:1395-1399.

Murashige, T. and F. Skoog. 1962. A revised medium for rapid growth and bioassays with tobacco tissue culture. Physiol. Plant. 15:473494.

Nuraini, I. and J.M. Shaib. 1992. Micropropagation of orchids using scape nodes as the explant material. Acta Hort. 292:169-172.
Pedroza-Manrique, J. and Y. Mican-Gutiérrez. 2006. Asymbiotic germination of Odontoglossum gloriosum Rchb.f. (Orchidaceae) under in vitro conditions. In Vitro Cell. Dev. Biol. Plant 42:543-547.

Ramsay, M.M. and K.W. Dixon. 2003. Propagation science, recovery and translocation of terrestrial orchids. In: Dixon, K. W., S.P. Kell, and P.J. Cribb (eds.). Orchid conservation. Natural History Publications (Borneo), Kota Kinabalu, Sabah.

Rodríguez, F.L.M. 2000. Germinación y desarrollo in vitro de Paphiopedium exstraminodium (Castaño, Hágsater \& Aguirre) V. A. Albert \& Börge Pett. y P. caudatum (Rolfe) V. A. Albert \& Börge Pett. (Orchidaceae), especies en peligro de extinción. MS Thesis, Nat. Univ. of Mexico.

Sampaio, M.J.L., G.C. Stancato, and B. Appezzato-DaGlória. 2010. Direct regeneration of protocormlike bodies (PLBs) from leaf apices of Oncidium flexuosum Sims (Orchidaceae). Plant Cell Tissue Organ Cult. 103:411-416.

Santos-Díaz, M.S. and C. Carranza-Álvarez. 2009. Plant regeneration through direct shoot formation from leaf cultures and from protocormlike bodies derived from callus of Encyclia mariae (Orchidaceae), a threatened Mexican orchid. In Vitro Cell. Dev. Biol. Plant 45:162170 .

Santos-Hernández, L., M. Martínez-García, J.E. Campos, and E. Aguirre-León. 2005. In vitro propagation of Laelia albida (Orchidaceae) for conservation and ornamental purposes in Mexico. HortScience 40:439-442.

Sarasan, V., R. Cripps, M.M. Ramsay, C. Atherton, M. Mcmichen, G. Prendergast, and J.K. Rowntree. 2006. Conservation In vitro of threatened plants-Progress in the past decade. In Vitro Cell. Dev. Biol. Plant 42:206-214.

SEMARNAT. 2002. Norma Oficial Mexicana NOM-059-ECOL-2001. Protección ambientalEspecies nativas de México de flora y fauna silvestres-Categorías de riesgo y especificaciones para su inclusión, exclusión o cambioLista de especies en riesgo. Diario Oficial (6 de marzo 2002). México, D.F

Soto-Arenas, M.A., E. Hágsater, R. JiménezMachorro, G. Salazar-Chávez, R. Solano-Gómez, R. Flores-González, and I. Ruíz-Contreras. 2007. Las Orquídeas de México. Catálogo digital. Disco Interactivo Multimedia, Win-Mac. Herbario AMO. Instituto Chinoín, A.C., México.

Soule, L.C. 1981. The culture of Oncidiums. Amer Orch. Soc. Bull. 50:404-410.

Teixeira da Silva, J.A., N. Singh, and M. Tanaka. 2006. Priming biotic factors for optimal protocorm-like body and callus induction in hybrid Cymbidium (Orchidaceae), and assessment of cytogenetic stability in regenerated plantlets. Plant Cell Tissue Organ Cult. 84:135-144.

Thompson, D.I., T.J. Edwards, and J. van Staden. 2006. Evaluating asymbiotic seed culture methods and establishing Disa (Orchidaceae) germinability in vitro: Relationships, requirements and first-time reports. Plant Growth Regulat. 49:269-284

Yam, T.W. and M.A. Weatherhead. 1988. Germination and seedling development of some Hong Kong orchids. Lindleyana 3:156-160. 